\title{
The Combination of Logic and Practice is the Cornerstone of the School Governance Model Under the Super-Ministry System
}

\author{
Gu Jijian, Lu Sihong* \\ Chongqing Vocational College of Transportation, Chongqing Jiangjin 402247
}

\begin{abstract}
Schools implement super-ministry reform, and the focus of their school governance model has greatly deviated from this impact. The setting, role, authority, and order release of the school party and government leadership have all adversely affected department governance. Therefore, we propose that the starting point of school governance should be a combination of logic and practice constructed by the office's chief and deputy directors, the secretary of the Youth League general branch, the teaching secretary, and the executive secretary, only they can constitute the most basic starting point for decision-making.
\end{abstract}

Keywords: super-ministry, school, decision-making distribution, combination of logic and practice

\section{School Governance Setting under Super-ministry Reform}

Some schools have implemented super-ministry reforms, and this reformed governance model implements "department-realistic, division-nihilistic and section-realistic". That is, to outside, it is called division, but to inside, it is called department. Or we can say, to inside, department is real, but division is windy, and section-level posts are executive posts. This has set a keynote for the school's administrative governance. Schools follow the basic principle of "the party committee leadership is at the core, principals are responsible for administration and scholars pay attention to academics", and at the same time, the school leadership system emphasizes "party and government work in cooperation and joint responsibility". The ratio of position is explicitly stipulated. Generally, there are five leaders of division level and the positions in their departments can be set at their own discretion. Usually it is equipped with office directors, deputy directors, and the secretary of the Youth League general branch, or the director and deputy director as one, and the secretary of the Youth League general branch. Under that there are approximately 1-4 teaching secretaries, executive secretaries, etc. so the range of school department staff is 2-6. But there is only one department with 6 posts in our survey, the rest are around 4; this is a big difference, and it challenges the school governance. The survey found that the proportion of division / section posts is concentrated between $100 \%$ and 167 . \% (Only one school is $83 \%$ ). All materials collation, teaching implementation, expenditure use, student management must be completed by section-level staff. This is the current governance model of some schools.

\section{The crux of school governance issues}

The substantial problem in the reform of the government's administrative department is Sun Xueyu's "concentrate closely related functions in a large department and exercise them uniformly", and Zuo Ran's "reorganize some departments with similar functions or functionally related departments into a large department, and the original ministries are built into functional departments and bureaus, or a certain independent institution managed by ministries"; or as "Outlook Weekly" and "Daily Economy" and other media believe that "the management is carried out by a single department to avoid the overlapping of government functions, multiple administrations, and multiple management to the maximum extent, so as to achieve the goal of improving administrative efficiency and reducing administrative costs "(Wang Sifang, 2008). Such schools have almost adopted the path of administrative governance in the process of implementing super-ministry reform. However, the structural setting of "department-realistic, division-nihilistic and section-realistic" has clearly shown that the core management philosophy of school governance deviates from the original intention of the super-ministry system, and the school division / section post ratio is a proof. In the process of governance, the school's responsibilities need to be distinguished significantly, but it is difficult to distinguish the staffing; once the responsibilities are not clear enough, the free-riding behaviour and moral hazard problem will inevitably occur, especially in high IQ concentration areas, because it is the practical operating unit of people flow, logistics, and capital flow. As the concentration of resources, it means that conflict and harmony are fused here. The study found that there are the following aspects of the problem in schools under the super-ministry system. 


\section{First, bureaucratization at the school department-level leaders}

One of the characteristics of the super-ministry system should be the reduction of the school (deputy) ministerial level. It has a macro grasp of major policies and principles but is not responsible for the implementation of specific details. In this way, all five (deputy) ministerial levels are directing and coordinating the school's development and planning, the division of labor is clear and detailed, but the field is narrow, and their workload and work area are far lower than the macro level that a (deputy) ministerial leader should coordinate. Therefore, under the thinking of "department-realistic, division-nihilistic", they naturally guide work and release instructions but do not do specific tasks. We don't know whether this is in line with the original intention of "the school's establishment of the division seems to mainly reduce the pressure of school administration, the department should have more substantial administrative power", "but in reality, the department, which is under the leadership of the school and relative departments, is not becoming a real administrative management Center. It only serves as the school's dispatch agency or administrative subordinate and can only find its own space between the school, which is the decision maker, and the real department, which is the actual operator." (Li Suqin, 2008). In the process of department management, these people basically only need to convey information and attend meetings. Specific tasks are finished by the section - level staff completely.

\section{Second, unwise school decision-making}

The bureaucratic tendency and helplessness of the department-level leaders of the school are manifested in a situation that the decision-making implementation process is basically an empirical approach or a collective voting of the department-level leaders. On one hand, there is no passion, conditions and action, and they lack the thinking that research forms decisions. On the other hand, the department-level leaders do not realize that they should be the center of the school to lead the department. So, requiring them to grasp the macro situation is tantamount to engage in idle theorizing. In this case, the school's decisions-making on important things is often unwise. For example, when they decide to set the number of student party branches in their school where there are 600-700 students, they take it for granted that one student party branch is easier to manage, but they do not investigate from practice, such as different management methods of different counsellors, the differences between senior and lower grades, workload of a branch secretary, etc. And they do not listen to the grassroots staff, but directly make decisions in the school office meetings, and then the grassroots staff are responsible for implementation.

\section{Third, the deformity of school posts}

In view of the above two points, the school's scientific research promotion, discipline construction, student management, affiliation of the party members and masses, document circulation, department coordination, financial replacement, and other aspects are carried out by a small number of staff in the post. The department-level leaders can command the staff to follow and implement without principle. As a result, the staff do not have any real power but claim all trivial and important matters. They handle daily affairs quickly and energetically all the time. They have no room for thinking and improvement. This abnormal working mode is an embodiment of malignant occupational disease. It makes the implementation become mechanical, and everything is non-negotiable.

\section{REFLECTIONS ON THE REFORM OF SCHOOL GOVERNANCE}

Mentioned the school's governance structure under the super-ministry reform, we must start from the real crux to seek a more reasonable governance structure, rather than just grafting the shell of the government's super-ministry reform. We believe that the starting point of school governance should be the logical and practical unit of the office's chief and deputy directors, the secretary of the Youth League general branch, the teaching secretary, and the administrative secretary. Only they can constitute the most basic starting point for decision-making. For this purpose, the following points need to be achieved:

\section{First, administrative decentralization}

The so-called administrative decentralization means that the school's decision exercise of specific administration, teaching, and student matters must be transferred to the section-level posts. Only they can truly understand the real ideas of teachers and students, which are not easily revealed in front of the school leaders. However, how to do it is another problem. It is easy to have another kind of unbridled and unbalanced situation. In view of this, the leaders of school should learn to focus on the macro-level at first, and they only need to clarify the responsibilities, rights, and permissions required by the principles, rules, and systems. "Through the establishment of various rules and regulations, the original management methods have been changed from specific management to monitoring management, and management tools have been changed from direct management to indirect management. that is, by implementing macro-control of departments to reduce the blindness of management and enhancing the scientific nature, which is conductive to the continuity of management activities." (Jiang Shu, 2007). 


\section{Second, respective duties of the school's party and government}

This proposal is made on the basis of administrative decentralization, and it is actually the same source. That is, under the super-ministry system, each school has only two department-level leaders, principal and party secretary, Secretary doubles as vice principal. They negotiate the division of labor on their own. Compared with the current department levels, the other school department-level and division-level posts are set to section-level posts. That is, we have two full-time leaders in three positions to take charge of all the day-to-day running of school, also including scientific research management rights and personnel and financial power of the school. They two focus on the scale, quality, and efficiency of the school but decentralize all other details. By overall planning and assessment, they can successfully monitor the development of school. It is not necessary to set up a large number of department-level leaders, for it is easy to cause discord caused by moral hazard.

\section{Third, section-level posts first}

This point is closely tied to the above two principles. Under the premise of the implementation of these two points, the operation and implementation of all the specific affairs of the school, the preliminary planning, the administrative behavior, and the assessment of the separation of power and responsibility are all performed by the section-level posts. Put strict assessment to these posts' contribution to the school's development and control, and set a certain number of systematic posts among them, and implement a hierarchical system, that is, same section-level posts with different treatment and post authority. The reduction of department-level posts is directly distinguished from the ordinary section-level posts. The person who enjoys the department-level and deputy department-level treatment at the section-level post will lead all the personnel of the section, but he must at first be a pure and pute performer and section-level administrative staff at school, and then the supervisors and coordinators of the section-level posts and the center of the leaders of the school's party and government. Before implementation of all school affairs, they should attend the meetings and discussions. Their implementation of school policies and systems is easier to approach reality, and also easier to develop the particularity of their own department. But such design will also bring possible risks, which we will continue to explore in the following measures.

\section{Fourth, assessment first}

In view of the section-level posts first, we must consider how to limit and prevent the agency mechanism, free-riding, and moral hazard caused by the increase of posts' authority. So, a strict responsibility assessment system is inevitable. that is, the assessment of responsibility and authority comes first. In our proposal, although the staff of the section-level posts do not have much substantial power, the interest trend and disposal of interests in the implementation link may cause a qualitative change in the original intention of the school's design, which must not be ignored. We must overcome the phenomenon that "There is often an obvious non-corresponding relationship between power and responsibility-responsibility is in a state of "shrinking", which leads to a "state of pan-power". The aim is to achieve a harmonious unity of responsibility and power, so that administrative staff can form a benign professionalism. We must shape the "sense of duty" of administrative staff "(Wang Binbin etc., 2008). The administrative assessment should be carried out in parallel with economic assessment, and strict rewards and punishments system is strictly implemented. Only by doing so we can lay the foundation for a virtuous circle of departmental governance.

\section{Fifth, distribution of decision-making}

The above four suggestions are the groundwork for the core idea of distribution of decision-making. One of the roads that must be followed to implement a benign governance structure for schools under the departmental system is distribution of decision-making. Since the section-level posts are the connection of grass roots and middle, they are familiar with both the needs and crux of the grassroots, and understand the strategy of the school. So, if the school wants to make a decision, it should turn the section-level posts' suggestions, compromises and transformation into prelude of decision-making implementation, but cannot use them as a prop for the school's execution. It can be designed that the office director, the office deputy director, the secretary of the youth league general branch, the teaching secretary, and the administrative secretary to form the school's logic and practice unit under the coordination of the office director. We say that they are the combination of practice and logic because they are the first link of practical execution and the junction of theoretical and logical traceability. Only after this stage of precipitation and filtering, can the school's decision-making science have vitality. Unlike the proposal and governance structure of "departmental decision-making mechanism, in which there are two levels and three forms. The general party branch meeting and the principal (division) office meeting are one level and the party and government joint meeting is another level. In the two levels, the party and government joint meeting is to reach consensus on the major issues of the department and form the final decision." (CCP Ningxia School Committee, 2004), it is more detailed. This is perhaps inheritance and improvement, but we firmly believe that our solution is more feasible and scientific. 


\title{
ACKNOWLEDGMENT
}

First of all, I would like to express my gratitude to all those who helped me during the writing of this thesis. I gratefully acknowledge the help of my supervisor, who has offered me valuable suggestions in the academic studies. In the preparation of this thesis, she has spent much time reading through each draft and provided me with inspiring advice. Without her patient instruction, insightful criticism and expert guidance, the completion of this thesis would not have been possible.

Second, I also owe a special debt of gratitude to all the professors in Foreign Languages Institute, from whose devoted teaching and enlightening lectures I have benefited a lot and academically prepared for the thesis. Last, I should finally like to express my gratitude to my beloved parents who have always been helping me out of difficulties and supporting without a word of complaint.

\begin{abstract}
About the Author:
Gu Jijian (1980.8) male, Han, Shandong, Ph.D., professor of Chongqing Vocational College of Transportation, mainly engaged in education management research.

*Corresponding Author: Lu Sihong(1984. 12), male, Han, Chongqing, master degree, lecturer of Chongqing Vocational College of Transportation, mainly engaged in English Translation Theory and Practice.
\end{abstract}

\section{REFERENCES}

[1] Wang Sifang. Review and Prospect of the Research on the Reform of the "Big Ministry" [j]. Contemporary Social Science Perspective, 2008. 2 p 35

[2] Li Suqin. An Analysis of the Status of Schools in China [j]. Modern School Education 20082 p 91

[3] Jiang Shu. Thoughts on Constructing Comprehensive Management Responsibility System in Secondary Schools [j]. Journal of Social Science of Shanxi Colleges and Universities, 2007.12 p 138

[4] Wang Binbin, Zhu Yifang's Administrative Power Misconduct and Regulation: A Study Based on Public Power Regulation Theory [j]. Heilongjiang Education (Higher Education Research and Evaluation), 2008.4 p 12

[5] Ningxia School Committee of the Communist Party of China. Innovating School Management System and Taking the Road of Leap-forward Development: Exploration and Practice of Substantial Reform of School Departments in Ningxia [j]. Journal of Ningxia School (Humanities and Social Sciences), 2003.3 p 6 